\title{
Professor Yudzuru Ogura and his Works
}

\author{
by Shunji WATARI*
}

\section{亘理俊次*：小倉誰教授と業績}

On June 26, 1955, Professor Yudzuru Ogura celebrated his sixtieth birthday and retired on March 31, 1956, after his nearly fourty years of long sincere and meritorious service to the University of Tokyo. For his lucid contributions, the University appointed him to emeritus professor, the Botanical Society of Japan dicided to honour him by the issue of this special number, and his direct associates and intimate acquaintances had a commemorative assembly on an evening in April.

Prof. Ogura was born in 1895 at Sendai City, passed there his childhood and youth, and educated at the Second Highschool. In 1916, he entered the College of Science, Imperial University of Tokyo and studied at the Botanical Institute. In the final course, he specialized in plant morphology under the direction of Prof. Kenjiro Fujii. Immediately after graduating from the University in 1919, he was appointed as lecturer of the University, received the degree of Doctor of Science in 1927, promoted to assistant professor in the same year, and, in 1938, to professor, a position which he was continued to occupy until his retirement.

In Feb. 1928 he started for Europe as a researcher sent from the Department of Education. After staying for several months at the British Museum, London, and Botany School, Cambridge, where he was acquainted with Dr. D. H. Scott and Prof. A. C. Seward, he went to Munich when Prof. Karl von Goebel was the Director of the Botanical Institute, and returned to Japan via United States in April, 1930. He visited Europe again in 1954 and attended the Eighth International Botanical Congress at Paris as a representative of Japan.

During these years, he contributed significantly to the University as a councillor and as the director of the Botanic Gardens. He is also in service, as a commettee or councillor, to the Department of Education, the Science Council of Japan, the Natural Science Museum, and other organizations. To the Botanical Society of Japan, he devoted especially for long years as a general secretary and councillor, and in the last ten years (1946-1955) he was continuously elected President. In every occasion, Prof. Ogura's attainment, sound judgement, unselfishness, and ardent service commanded the respect of all who came in contact with him.

Contributions to the morphology and anatomy of pteridophytes.

Immediately after the publishment of his earliest work on the growth in thickness of trees (1920), Prof. Ogura turned into the investigation on the pteridophytes,

\footnotetext{
* Botanical Institute, Faculty of Science, University of Tokyo. 東京大学理学部植物学教室
} 
commencing from an extensive historical review on their general structure (1921b). His first contribution in this field is "Gaps of stele in Polypodiaceae" (1921a) based upon more than thirty species of the family. His conclusion on the difference between the dictyostely and solenostely in this family is that it is irrespective of the length of the internode but chiefly owes to the length of gaps in the respective species.

In the meantime, his attention on many serious disagreements in the anatomy of the tree-ferns held by previous investigators led Prof. Ogura into his extensive studies on Japanese species of Cyathea, Alsophila, and Cibotium (1925 a-c, 1926a-d), and also on a polypodiaceaous tree-fern Diplazium esculentum (1927a). On the basis of these studies together with some additional observations he worked out a voluminous paper entitled "Comparative anatomy of the Japanese Cyatheaceae" by which he was granted a degree of Doctor of Science $(1927 \mathrm{~b})$. Among various features here described or discussed, a special importance seems to lie in an admirable explanation on the complicated stelar system of the stem which is mostly associated with the medullary bundles and also frequently with the cortical ones as well as of the petiole. He traced the origin of medullary bundles in young plants and found that they arised independently in the pith, but in the rare cases of the young form, they appeared from the innerside of the stele, suggesting that they might be derived from those of the polycyclic stele. He proposed here the names "Cyathean dictyostele" and "Alsophilan dictyostele", the latter differing from the former in the presence of cortical bundles which originate independently in the cortex. He further pointed out that the important structural features by which tribes of the family, i. e. Thyrsopterideae, Dicksoniae, and Cyatheae can be distinguished, are the types of stelar system in the stem, absence or presence of the sclerenchymatous sheath around the stele, and the characteristic arrangement of petiolar bundles.

On the way of his return to Japan from Europe, Prof. Ogura had an opportunity at Glenwood of the Island of Hawaii to collect three species of Cibotium, C. Chamissoi, C. Menziesii and a new species C. hawaiense Nakai et Ogura. He found (1930 b) that features of these species, especially an absence of the sclerenchymatous sheath around the dictyostele, are quite identical with the case of a well-known species with the creeping habit, C. Barometz, and he, hence, established a new tribe Cibotieae which stands very closely with the tribe Dicksonieae to which this genus had formerly been placed.

During his stay in Munich, 1929, Prof. Ogura studied the morphological and anatomical studies of Polypodium in a wider sense based on the specimen of the Munich University, and its results were published in 1935 . Here he described in detail the structure of hairs of the petioles, nerves and sporangia, and discussed the variablity of the genus. He added further two important papers. In a detailed study on the external and internal features of Oleandra Wallichii and other several species (1938b), he concluded that the root-like organ which springs out of the 
stem exogenously is to be understood as "rhizophore", and that the genus should be placed in an isolate phyletic position, an independent family, Oleandraceae. In another paper (1939), on the basis of a particular vascular course, especially of the medullary bundles, he established Acrostichum-type based on Acrostichum speciosum, which is slightly different from the Cyathean-type.

Building upon his own studies and on the basis of an accumulation of vast knowledge on the pteridophytes, he published in 1938, his comprehensive work "Anatomie der Vegetationsorgane der Pteridophyten" as a part of "Handbuch der Pflanzenanatomie". Here he established firmly his excellent stelar theory and published many precious conceptions, together with detailed descriptions on living and fossil members. To his great contributions to the anatomical works on pteridophytes, the Japan Academy honoured him, in 1946, with the bestowal of the Japan Academy Prize.

Contributions to the palaeobotany.

Since an account of the Cretaceous plants from Hokkaido was published by Stopes and Fujii in the Philosophical Transactions of the Royal Society of London (1910), more than fifteen years have elapsed without any noteworthy works on the petrified fossils, until Prof. Ogura published successively his papers since 1927. His work in this field was commenced from a study on the Mesozoic tree-ferns from Japan and Korea (1927 c), wherein he proposed three new species, i.e. Cyathocaulis naktongensis, Cibotiocaulis Tateiwae, and Cyathorachis Fujiiana, the latter being the very finely preserved petiole. The former two show the Cyathean-type of the dictyostely but differ from each other in the feature of the leaf-scar as well as in the arrangement of leaf traces. He studied many further specimens obtained by himself at Korea (1941 a) and several important features have been ascertained or added to these species. He pointed out here that the best feature in distinguishing these two species and C. Yabei (1941) from the Tertiary of Mindoro, Philippine Is., lies in the structure of medullary meristeles and their sclerenchymatous sheath. From these studies, he came to the conclusion that the differences between Cyathocaulis and Cibotiocaulis are too small to place them in different genera and united the latter to Cyathocaulis. He also described two fossils related to the Cyatheaceae, i.e., Protocyathea Tokunagai (1931) and Cibotium iwatense (1933) from the Upper Cretaceous of Japan, the latter being similar in the absence of medullary meristeles and of the sclerenchymatous sheath around the vascular bundles (cf. $1930 \mathrm{~b}$ ).

In 1928, Prof. Ogura spent many days at the British Museum for the examination of sections collected by Prof. Fujii and himself from the Cretaceous of Hokkaido. As soon as he returned to Japan, he published a paper (1930 a) in which he proposed Yezopteris polycycloides, a fern stem which is very close to the Cyatheaceae, Solenosteleopteris loxsomoides resembling Loxsoma of the Davalliae, a cycadean petiole Cycadeoidea petiolata, and a small and slender cycadean shoot Cycadeoidella 
japonica. Also he emended here Stopes and Fujii's description on Cunninghamiostrobus basing upon two new specimens. This work was soon followed by the second contribution (1932 a) which owes largely to the specimens obtained by himself in his two visits to Hokkaido during 1930 and 1931. Here he added Cycadangium compactum representing a new type of the cycadean microsporophyll, Stachycarpites projectus on the basis of seeds having an affinity to Podocarpus, especially to Stachycarpus, Piceophyllum simplex a leaf close to Picea or Larix, a three-leaved pine Pinus flabellifolia, a five-leaved pine Pinus pseudostrobifolia, Sciadopytis cretacea closely resembling to our living umbrella pine, and Yubaria invaginata which is a dicotyledonous petiole with uncertain affinity.

In the same year, Prof. Ogura described an extinct evergreen oak, Quercinium hobashiraishi (1932 b) by studying a huge silicified trunk, a famous natural monument "hobashiraishi" lying on the beach at Najima near Fukuoka City. It is to be remembered as the first sure record of the dicotyledonous wood from the Tertiary of Japan. He also found at the same place another noteworthy species, Phyllanthinium pseudohobashiraishi, an euphorbiaceous wood resembling especially to Bishoffia (1932 c). His third dicotyledonous wood Castanopsis Makinoi was published in 1949.

In the later year (1944), Prof. Ogura proposed five new species of coniferous woods, i.e. two Araucarioxylons, A. kiiense and A. jeholense, Taxodioxylon compressum, Cedroxylon simplex, and Pinuxylon microporosum. Also he added here a noteworthy knowledge to Xenoxylon latiporosum, a gymnospermous wood with a doubtful affinity, as well as a summarized information on Japanese Taxodioxylon. Although his interest on Xenoxylon latiporosum was shown already as early as 1931 when he briefly noted its occurrence from Korea, he described first in this account his careful observation on the thin-walled septa in the lumen of tracheids which are tyloses of tracheids derived from the adjacent ray cells. Several years later, numerous examples including a considerable number of erect stumps of this species were found from the Jurassic of Isikawa Prefecture, Japan (1951). He succeeded to observe the structure of a fairly well-preserved pith in one of them, on which he communicated at the Eighth International Botanical Congress held at Paris in 1954. Though the report in detail is not yet published, it is to be remarked here that the pith of Xenoxylon should be regarded as an ordinary coniferous type in its structure.

He studied also a large silicified stem base covered with crowded roots, sitting as ornament in the famous Kenroku park at Kanazawa City. Although its exact origin was uncertain, he identified it as a new species of Palmoxylon, P. Maedae, belonging to Stenzel's Cordata group of the Corypha type (1952a). Soon after, however, he found another closely related species, $P$. kagaense (1955 b), among the gravels at a river-bed of the same district. It was probably derived from a greentuff of the Miocene, and the finding of this species is particularly important since it immediately suggests, as he himself thought, a possible occurrence of P. Maedae at a certain locality of the same district. 
On the other hand, the sole but very important contribution on the Palaeozoic fossil was published in 1948, in proposing a new name Pecopteris samaropsis, a seedbearing Pteridosperm, from the Upper Permian of Penhisu coal fields, Manchuria. It was described on the basis of an excellent specimen with organic connection of frond and seed which have been known until that time as Pecopteris arborescens and Samaropsis affinis respectively.

Contributions to the morphology and anatomy of higher plants.

Prof. Ogura's earliest work "Some observations on the growth in thickness of trees" (1920) was carried out under the direction of Prof. Kenjiro Fujii during his final course of student (1919-1920). Of the woods of Cryptomeria and other several conifers and angiosperms, he measured extensively the width of annual rings and dimension of xylem elements in variable ages and heights, and he found several important correlations among them, some of them being nearly confirmative of Sanio's law, while his conclusion on the correlation between climatic factors, especially the amount of precipitation and the growth in thickness is rather negative.

After a fairly long interval during years when Prof. Ogura was busy in the study on the pteridophytes and Mesozoic fossils, he contributed again many important works in this field. In a paper dealt with several species of Blahdia (1937 b), he reported a new type of the branch abscission in $B$. Sieboldii and other species whose base of branch is especially widened, and when they disarticulate from the stem there leave large scars, on whose periphery vascular bundles are loosely arranged. On the basis of observations on the mangrove plants during his visit to the Micronesian Islands in summer of 1939, Prof. Ogura described (1940, 1942) two new tpyes of the aerial roots, "standing roots" (Urandia ammui and Glochidion hongkongenense) and "curving roots" (Horsfieldia amklaal). The first type resembles erect roots but differs in essentially similar structure with subterranean roots, and the second type is comparable with curved-knee roots but differs in the simpler shape and in the absence of abnormal thickenings. In his study on the branching habit in the genus Phyllanthus (1943), he showed that Ph. Matsumurae represents the simplest type in which only a kind of branch is present, whereas are seen two types of branches, i. e. long and short ones, in Ph. Urinaria and Ph. flexuosus, the latter differing from the former in more acceralated difference between both branch types.

During these years, Prof. Ogura also accomplished an extensive study on the dimension of bast fibers ( $1940 \mathrm{~b}$ ), in enlisting more than 350 species including some pteridophytes and gymnosperms as well as many dicotyledons and monocotyledons. In an observation on the formation of root tubers in Ipomoea Batatus (1945), he showed that the tubers are formed from the normal roots by the abnormal thickening due to the activity of cambia around the vessels.

Another series of interesting works published in recent years is observations 
in the morphology and anatomy of subterranean organ of some monocotyledons. In a study on the Liliaceae (1952 b,c) Prof. Ogura was especially aware of Erythronium japonicum whose club-shaped subterranean organ is provided with a curious appendage consisting of a certain number of segments. In going carefull comparisons with some allied genera such as Tulipa, Gagea and Lloydia, he came to a recognition that the club-shaped organ in Erythronium is a bulb caused by the fusion of two or three sheaths and its basal part is bulged out annually as a small segment, which remains as the peculiar appendage. He also studied Allium monanthum (1955) whose bulb consists of a few enclosed scale and includes usually one adventitious bulblet. Here he showed that the bulblet concerns in a peculiar way to the vegetative propagation, that is, it germinates in the next spring into a long stolon whose tip contains, at the base of leaf, usually two bulblets and one of them, the adventitious one, repeats the formation of stolon in the subsequent spring.

In another work (1953), Prof. Ogura treated many species of the Ophyrydinae of the Orchidaceae. In every plants, besides normal roots, there are one or two special subterranean organs which are provided with a bud in its certain part. On the basis of a precise anatomical study he recognized that the proximal portion is a combined system of a central cauline axis and peripheral root traces, while the distal portion is a combined system of some roots. He concluded that the proximal portion may be considered as a rhizophore which carries the distal portion of a radical character.

\section{Selected Bibliography}

1920 杉其他の樹木の肥大成長に関する二, 三の観察 (Some observations on the growth in thickness of trees, especially with regard to that of Cryptomeria japonica Don) Bot. Mag. Tokyo, 34: 146-162; 167-180; 185-194; English summary 91-109.

1921 a. On the gaps in the stele of some Polypodiaceae. Bot. Mag. Tokyo, 35: 115-125.

b. 羊霜植物の構造 (Structure of Pteridophytes) Scientific Gazette, 9: 299-315； 357-376; $433-455 ; 511-521$.

1925 a. ヘゴの㝤造 (On the structure of Cyathea spinulosa Wall.) Bot. Mag. Tokyo, 39: 1-28. b. メヘゴの㪹造 (On the structure of Alsophila Ogurae Hayata) Bot. Mag. Tokyo, 39 : 197-213.

c. クサマルハチの構造と類縁 (On the structure and affinity of Alsophila acaulis Makino) Bot. Mag. Tokyo, 39: 329-343.

1926 a. マルハチの構造 (On the structure of Alsophila Bongardiana Mett.) Bot. Mag. Tokyo, $40: 69-90$.

b. 本邦廉へゴ属の構造 (On the structure of the Japanese species of Cyathea) Bot. Mag. Tokyo, $40: 307-310$.

c. タカワラビの構造と類縁 (On the structure and affinity of Cibotium Barometz Sm.) Bot. Mag. Tokyo, $40: 349-359$.

d. 台湾丈び琉球産マルハチ属植物の構造 (On the structure of the species of Alsophila found in Formosa and Loochoo) Bot. Mag. Tokyo, 40:401-417. 
1927 a. On the structure of Diplazium esculentum (Retz.) Sw. Bot. Mag. Tokyo, 41: 172-180.

b. Comparative anatomy of Japanese Cyatheaceae. Jour. Fac. Sci. Imp. Univ. Tokyo, Sect. 3, $1: 141-350$.

c. On the structure and affinities of some fossil tree-ferns from Japan. Jour. Fac. Sci. Imp. Univ. Tokyo, Sect. 3, 1: 351-380.

d. 本邦産現代丈中世代の杪欏科植物の構造について（Structure of Japanese Cyatheaceae, living and Mesozoic) 東洋学芸雑誌, Tôyô-Gakugei-Zasshi, 43: 507-519.

1930 a. On the structure and affinities of some Cretaceous plants from Hokkaido. Jour. Fac. Sci. Imp. Univ. Tokyo, Sect. 3, 2: 381-412.

b. On the structure of Hawaiian tree ferns, with notes on affinities of the genus Cibotium. Bot. Mag. Tokyo, 44 : 467-479.

c. 植物系統解剖学 (Phylogenetic Plant Anatomy) 岩波講座生物学, 84 pp. (Tokyo).

1931 On a fossil tree fern stem from the Upper Cretaceous of Iwaki, Japan. Jap. Jour. Geol. and Geogr. 9: 55-60.

1932 a. On the structure and affinities of some Cretaceous plants from Hokkaido. II. Jour. Fac. Sci. Imp. Univ. Tokyo, Sect. 3, 2: 455-483.

b. On the structure of "hobashira-ishi", a famous silicified trunk at Najima near Fukuoka City. Jap. Jour. Bot. 6 : 173-181.

c. On the structure of silicified wood found near "hobashira-ishi" at Najima near Fukuoka City. Jap. Jour. Bot. 6: 183-190.

1933 On the structure of a fossil fern stem of Cibotium-type from the Upper Cretaceous of Iwate. Bot. Mag. Tokyo, $47:$ 748-754.

1934 植物形態学 (Plant Morphology.) 養蜸堂, 654 pp. (Tokyo) (1941-2 版, 1944-3 版, 1947-4 版, 1948-5 版, 1949-6 版).

1935 ウラボシ属の形熊学的観察 (Morphologische Beobachtungen der Gattung Polypodium) 植物 研究雑誌 Jour. Jap. Bot. 11: 673-687; 741-760.

1936 Phylloglossum Drummondii に就いて (On Phylloglossum Drummondii) (亘理俊次と共著, with S. Watari) 植物及動物, Botany \& Zoology, 4: 29-42.

1937 a. 植物形態学上の諸問題 (Problems in Plant-Morpology.) 植物区動物 Botany \& Zoology 5 : 175-184; 553-560 ; 729-738 ; 889-898; 1067-1078 : 1237-1248; 1407-1414 ; 1573-1584; $1757-$ $1768 ; 1933-1942 ; 2111-2117 ; 2171-2279$.

b. Disarticulation of the branches in Blahdia. Bot. Mag. Tokyo, 51: 158-167.

1938 a. 植物形態学上の諸問題 (Problems in Plant-Morphology) 植物及動物, Botany \& Zoology, 6 : 139-148; 497-506; 661-668; 833-843；981-990；1157-1163；1307-1314 ; 1457-1465；16191627 ; 1723-1784; 1945-1952; 2097-2102.

b. Anatomy and morphology of Oleandra Wallichi (Hk.) Pr.,with some notes on the affinities of genus Oleandra. Jap. Jour. Bot. 9: 193-211.

c. 植物解剖学実験法 (Methods in Plant Anatomy) 建交館講座, 14: 96 pp. (Tokyo).

d. Anatomie der Vegetationsorgane der Pteridophyten. Handb. d. Pflanzenanatomie, II-7 (2, B) 476 S. (Berlin).

1939 ミミモチシダ属の解剖学的構造に関する批判 (Critical notes on the anatomical structure of Acrostichum) Bot. Mag. Tokyo, 53 : 540-548.

1940 a. New examples of aerial roots in tropical swamp plants. Bot. Mag. Tokyo, 54: 327-337.

b. 勒皮繊維の大きさに関する測定（Measurement of the size of bast fibers）紡績界, Bôse- 
kikai, $31: 38-52$.

c. 東京帝国大学理学部植物学教室沿革. 附理学部附属植物園沿革 (History of the Botanical Institute, Faculty of Science, Imperial University of Tokyo. Appendix: History of the Botanic Gardens, Faculty of Science) 342 pp. (Tokyo).

d. マングローブ显地植物の異常根の諸型について (On the types of abnormal roots in mangrove and swamp plants) Bot. Mag. Tokyo, 54: 489-404.

1941 a. Additional notes on the structure of fossil tree ferns. Bot. Mag. Tokyo, 55: 453-461.

b. On the structure of a fossil tree fern stem from Mindoro, Philippine Islands. Jubilee Publ. Prof. Yabe, 911-917.

1942 東亜に於けるマングローブ植物（Mangrove plants in the Eastern Asia） 植物区動物, Botany \& Zoology, 10 : 145-149; 233-237.

1943 a. エミカンソウ属の二形枝に就いて (On the dimorphic branches in Phyllanthus) 植物支 動物, Botany \& Zoology, $11: 13-16$.

b. 葉の起原文発澾に関する形熊学的並に系統学的考察 (Morphological and phylogenetic considerations on the origin and development of the leaves) Bot. Mag. Tokyo, $57: 388-399$.

1944 Notes on fossil woods from Japan and Manchukuo. Jap. Jour. Bot. 13: 345-365.

1945 甘諸の塊根形成に関する解剖学的研究 (Anatomical study on the formation of root tuber in Ipomoea Batatus) 農業及園芸, Agriculture \& Horticulture, 20 : 331-340；381-390.

1948 A new example of seed-bearing Pteridosperms from Manchuria, Proc. Jap. Acad. 24 : 1-4.

1949 a. Fossil wood of Castanopsis-type from the Tertiary of Nagano Prefecture. Jour. Jap. Bot. 24 : 15-18.

b. 㴖洲産の種子を着けた羊米種子類の一新例 (A new example of seed-bearing Pteridosperms from Manchuria) Bot. Mag. Tokyo, 62: 729-730.

c. 植物解剖改器官学 (Anatomy and Organography of Plants) 養賢堂, $232 \mathrm{pp}$. (Tokyo) (1951-2 版, 1952-3 版, 1954-4 版, 1956-5 版).

1950 羊幽種子類の諾問題 (Some problems on the Pteridosperms) 植物学選集, ShokubutsugakuSenshu, 87-98.

1951 (With T. Kobayashi and S. Maeda) Discovery of erect stumps of Xenoxylon latiporosum in the Jurassic Tetori Series in Japan. Transact. Proc. Palaeont. Soc. Jap. $4: 113-119$.

1952 a. A fossil palm in Kenroku Park at Kanazawa. Transact. Proc. Palaeont. Soc. Jap. 7 : 223-230.

b. Morphology of the subterranean organs of Erythronium japonicum and its allies. Phytomorph. 2 : 113-122.

c. カタタリ攵びその近縁種の地下器官の形熊 (Morphology of the subterranean organs of Erythronium japonicum and its allies) Jour. Jap. Bot. $27: 35-45$.

1953 Anatomy and morphology of the subterranean organs in some Orchidaceae. Jour. Fac. Sci. Univ. Tokyo, Sect. 3, 6: 135-157.

1955 a. Abnormal growth in Allium monanthum. Bot. Mag. Tokyo, 68: 76-80.

b. A fossil palm trunk from Kanazawa. Transact. Proc. Palaeont. Soc. Jap. 19: 85-87. 